\title{
Growth traits of crossbreds of Ankole with Brown Swiss, Holstein Friesian, Jersey, and Sahiwal cattle in Rwanda
}

\author{
Maximillian Manzi ${ }^{1,2,3} \cdot$ Lotta Rydhmer $^{1} \cdot$ Martin Ntawubizi $^{3} \cdot$ Callixte Karege $^{3} \cdot$ Erling Strandberg $^{1}$
}

Received: 29 August 2017 / Accepted: 10 December 2017 / Published online: 19 December 2017

(C) The Author(s) 2017. This article is an open access publication

\begin{abstract}
The objective of the study was to compare body weights and growth from birth to 18 months of age of various groups of crossbred cattle born from 1999 to 2007, being crossbreds of Ankole (A) with Brown Swiss (B), Holstein Friesian (F), Jersey (J), and Sahiwal (S). Average weights were $26.5 \mathrm{~kg}$ at birth, $161 \mathrm{~kg}$ at weaning, and $226 \mathrm{~kg}$ at 18 months. Both season and sex significantly affected birth weight (BW), weight at 8 and 18 months (W8 and W18), and average daily gain from weaning to 18 months (ADG18) and, unlike season, sex significantly affected average daily gain to 8 months and weaning age. The general trend was that average daily gain attained a maximum before weaning and thereafter decreased until 18 months. Least square means for $\mathrm{AB}$ and $\mathrm{AF}$ calves were comparable and significantly differed only for $\mathrm{W} 18$ and ADG18. AJ had the lowest BW but was comparable with AS, AJxS, and ASxJ for W8, age-adjusted weaning weight, and W18. Generally, AF was heavier than other breed groups, but the difference was smaller than expected probably because environmental conditions did not allow full expression of genetic potential for growth.
\end{abstract}

Keywords Breeds $\cdot$ Live weight $\cdot$ Growth traits $\cdot$ Crossbreeding

\section{Introduction}

The Ankole is a medium-sized breed with males maturing at a live weight of 350 to $400 \mathrm{~kg}$ and females at 200 to $350 \mathrm{~kg}$. Milk production per animal per day ranges between 1 to $6 \mathrm{~kg}$ (Kugonza et al. 2011). Newborn calves weigh about 14-23 kg and remain small for several months. The breed like other breeds in tropics is characterized by low-productivity and low-growth rates but highly adapted to harsh environments (Wurzinger et al. 2014). In contrast, Bos taurus breeds that are predominantly found in temperate countries have a highproduction potential, but poor adaptation to tropical hash environment (Roschinsky et al. 2015). Therefore, crossbreeding of $B$. indicus with $B$. taurus breeds has been widely used in most African countries, including Rwanda, to combine the

Maximillian Manzi

manzi.maximillian@slu.se

1 Swedish University of Agricultural Sciences (SLU), Uppsala, Sweden

2 Rwanda Agricultural Board (RAB), Kigali, Rwanda

3 University of Rwanda (UR), Butare, Rwanda high-production potential of exotic breeds with the adaptability of the indigenous breeds.

Pre-weaning and post-weaning growth are important traits to select for in cattle (Pravia et al. 2014), but in Rwanda, there is a paucity of information on body weights and gains of Ankole cattle crossbreds. Therefore, information on preweaning and post-weaning growth was collected and analyzed to shed some light on comparative growth potential of different crossbred groups at a research station. The objective of this study was to identify suitable crosses by comparing body weights and weight gains of crossbreds of Ankole with Brown Swiss, Holstein Friesian, Jersey, and Sahiwal.

\section{Material and methods}

\section{Location and climatic conditions}

Data were from Songa Research Station $\left(2^{\circ} 25^{\prime} \mathrm{S}, 29^{\circ} 48^{\prime} \mathrm{E}\right)$, located in the mid-altitude zone (1471 m.a.s.l), with short rains (season SRS) falling between September and December and long rains (season LRS) extending from March through May. The dry seasons extend between June and August (LDS) and January to February (SDS). The mean annual rainfall was 
$1087 \mathrm{~mm}$ and average temperature of $20.1^{\circ} \mathrm{C}$, with relative humidity of $77 \%$ (Mutimura et al. 2016). The natural grass is predominantly composed of Brachiaria decumbens and limited planted multipurpose trees like Calliandra calothyrsus and Leucaena leucocephala.

\section{Animal and herd management}

The animals used in the study included 811 calves at birth, 781 calves at 8 months, 493 calves weaned, and 457 animals at 18 months of age. Female calves were mainly kept as potential replacement cows. Most male calves were sold for slaughter after 6 months, while others were sold to farmers as breeding bulls. Weaning was done in groups when calves were 813 months based on judgment of calf vigor and survivability. Partial milking was practiced, whereby calves suckled briefly to stimulate milk let-down and after milking were allowed to suckle residual milk. The animals were kept and grazed on paddocked natural pasture without supplementary feeds, and only calves were kraaled. Routine veterinary attention was provided to each animal.

\section{Data and statistical analysis}

Data used in this study were obtained from crossbred calves born from 1999 to 2007 of Ankole (A) or crossbred dams (AJ and AS) with Brown Swiss (B), Friesian (F), Jersey (J), and Sahiwal (S) sires (semen). Breed groups (crosses) are designated by the combination of breed acronyms, e.g., AJ $\times \mathrm{S}$ for an Ankole $\times$ Jersey crossbred mother with a Sahiwal father. For each calf, records included breed group, sex, dates, and weights from birth to 18 months of age. Weight records were taken monthly using weight balance, but for this study, the following weight traits were analyzed: (a) birth weight (BW) recorded within $24 \mathrm{~h}$ of birth, (b) weight at approximately 8 months (W8), (c) weaning weight (WWadj) adjusted to 10 months, (d) weaning weight unadjusted (WW), and (e) weight around puberty recorded at 18 months (W18). Furthermore, we analyzed the following growth rate traits: (a) average daily gain to 8 months (ADG8), computed as (W8-BW)/AGE8, (b) pre-weaning average daily gain (ADGW, from birth to weaning) computed as (WW-BW)/ AGEW, (c) post-weaning average daily gain (ADG18, from weaning to 18 months) computed as (W18-WW)/(AGE18AGEW), where AGE8 (AGE18) is the age of the animal at the monthly weighing closest to 8 (18) months of age and AGEW is the recorded age at weaning. Furthermore, we investigated the trait age at weaning (AGEW).

After removing observations with missing records, there were about 800 records for BW, W8, and ADG8 and around 400-500 records for the other traits (Table 1). The distribution of observations over sex and breed groups is shown in Table 2.

\section{Statistical analysis}

Data were analyzed using General Linear Models (GLM) procedure of SAS (2012). The most complete model tested was as follows:

$$
\begin{aligned}
y_{i j k l m}= & \mu+\mathrm{bg}_{i}+\operatorname{sex}_{j}+\mathrm{yr}_{k}+\text { seas }_{l}+(\mathrm{bg} \times \mathrm{sex})_{i j} \\
& +(\mathrm{bg} \times \text { seas })_{i l}+(\operatorname{sex} \times \text { seas })_{j l}+e_{i j k l m}
\end{aligned}
$$

where $\mathrm{y}_{i j k l m}$ is the observation for a given trait; $\mu$ is the overall mean; $\mathrm{bg}_{i}$ is the fixed effect of breed group $i(i=\mathrm{AB}, \mathrm{AF}, \mathrm{AJ}, \mathrm{AS}$,

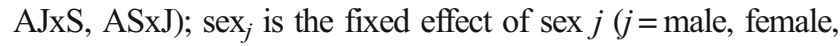
unknown); $\mathrm{yr}_{k}$ is the fixed effect of birth year $k(k=1999, \ldots$ 2007); seas $_{l}$ is the fixed effect of birth season $l(l=1,2,3,4)$; and $e_{i j k l m}$ is the random residual $\sim \mathrm{ND}\left(0, \sigma_{e}^{2}\right)$. For the weights at $\mathrm{W} 8$, WWadj, and W18, a linear regression on the actual age as a deviation from the expected age (240, 300, and 540 days) was included. Two-way interactions are shown within parentheses. Least Square Means (LSM) were computed to estimate differences among means of traits for different factors.

\section{Results}

The number of observations, overall means, standard deviations, and ranges observed for all traits studied together with significance levels for factors in the model and the least square means for the all main effects are presented in Table 1. The distribution of observations over breed groups and sex classes is shown in Table 2. Least Square Means for breed group, sex, and season are shown in Table 3.

\section{Comparison of breed groups}

The AJ calves were significantly lighter at birth $(25.8 \mathrm{~kg})$ than the other breed groups, which did not differ from each other (27.5$28.4 \mathrm{~kg}$ ) (Table 3). For WWadj, AB and AF were heavier than the other four groups (AJ, AS, AJxS, and ASxJ); however, without adjustment for weaning age, AF was significantly heavier than all other breed groups. Furthermore, AB, ASxJ, and AJxS did not differ significantly from each other but were all heavier than AJ and AS. For W8, the same tendency could be seen but only $\mathrm{AB}$ was significantly different from the last four groups. At 18 months, AF was heavier than AJ, AS, and also AB. Although $\mathrm{AJXS}$ and ASxJ were approximately 14 and $11 \mathrm{~kg}$ lighter than AF, respectively, the difference was not significant (Table 3).

Generally, the trends for the average daily gain traits followed those for the weights; $\mathrm{AB}$ and $\mathrm{AF}$ had higher the average daily weight gain, but these differences were not always significantly different from the other four breed groups. A general trend was that the daily weight gain reached maximum at or before weaning and decreased thereafter up to 18 months. AF and $\mathrm{AB}$ calves performed similarly in daily 
Table 1 The total number of observations, overall mean, $\mathrm{SD}$, and range for all traits investigated

\begin{tabular}{|c|c|c|c|c|c|c|c|c|c|}
\hline \multirow[t]{2}{*}{ Trait $^{1}$} & \multicolumn{4}{|c|}{ Measure } & \multicolumn{5}{|l|}{ Factor } \\
\hline & $N$ & Mean & SD & Range & $\mathrm{bg}^{2}$ & Sex & Year & Season & $b g \times \operatorname{sex}$ \\
\hline BW & 811 & 26.5 & 3.7 & $12-50$ & 0.0001 & 0.0420 & 0.0001 & 0.0341 & n.s. \\
\hline W8 & 781 & 123 & 21.4 & $65-229$ & 0.0004 & 0.0017 & $<0.0001$ & 0.0287 & n.s. \\
\hline WW & 493 & 161 & 33.2 & $74-285$ & 0.002 & n.s. & $<0.0001$ & n.s & $-{ }^{3}$ \\
\hline W18 & 457 & 226 & 34.2 & $88-346$ & 0.001 & n.s. & $<0.0001$ & 0.0133 & $-{ }^{3}$ \\
\hline ADG8 & 779 & 0.40 & 0.09 & $0.16-0.65$ & 0.0152 & 0.0067 & 0.0018 & 0.0004 & n.s. \\
\hline ADGW & 485 & 0.41 & 0.09 & $0.17-0.80$ & 0.0018 & 0.0057 & $<0.0001$ & n.s & n.s \\
\hline ADG18 & 424 & 0.36 & 0.10 & $0.07-0.74$ & 0.0014 & n.s & $<0.0001$ & n.s & -3 \\
\hline AGEW & 491 & 330 & 67.4 & $125-583$ & 0.1602 & $<0.0001$ & 0.0165 & $<0.0001$ & 0.0205 \\
\hline
\end{tabular}

The levels of significance ( $p$ values) for all main effects and their possible interactions. Significance levels are given for the model where all significant effects are included and non-significant effects excluded

${ }^{1} B W$ birth weight $(\mathrm{kg}), W 8$ weight $(\mathrm{kg})$ at 8 months of age, $W W$ weaning weight $(\mathrm{kg}), W 18$ weight $(\mathrm{kg})$ at 18 months, $A D G 8$ average daily gain (g) to 8 months, $A D G W$ pre-weaning daily gain ( $\mathrm{g}$ ), $A D G 18$ postweaning daily gain (g) up to 18 months, $A G E W$ age at weaning (days)

${ }^{2} b g$ breed group

${ }^{3}$ Indicates that this interaction was not tested because one or both of the main effects were non-significant weight gain up to weaning; however, at 18 months of age, $\mathrm{AF}$ outperformed AB significantly (Table 3 ).

\section{Discussion}

\section{Comparison of breed groups}

\section{Birth weight}

The $\mathrm{BW}$ of $\mathrm{AF}$ and $\mathrm{AB}$ crosses were not significantly different from each other; however, they were significantly higher than

Table 2 Distribution of observations over breed groups and sex classes

\begin{tabular}{|c|c|c|c|c|c|c|c|c|c|}
\hline \multirow[t]{2}{*}{ Trait $^{1}$} & \multicolumn{6}{|c|}{ Breed group ${ }^{2}$} & \multicolumn{3}{|l|}{ Sex } \\
\hline & $\mathrm{AB}$ & $\mathrm{AF}$ & $\mathrm{AJ}$ & AS & AJxS & ASxJ & Female & Male & Unknown \\
\hline BW & 41 & 46 & 346 & 189 & 86 & 103 & 338 & 170 & 303 \\
\hline W8 & 38 & 47 & 330 & 183 & 82 & 101 & 325 & 168 & 288 \\
\hline WW & 39 & 38 & 162 & 128 & 61 & 65 & 320 & 160 & 13 \\
\hline W18 & 16 & 27 & 146 & 128 & 65 & 75 & 250 & 66 & 141 \\
\hline ADG8 & 38 & 46 & 330 & 182 & 82 & 101 & 325 & 168 & 286 \\
\hline ADGW & 38 & 38 & 161 & 124 & 61 & 63 & 313 & 159 & 13 \\
\hline ADG18 & 13 & 27 & 129 & 121 & 61 & 73 & 237 & 64 & 123 \\
\hline AGEW & 38 & 38 & 162 & 126 & 61 & 66 & 316 & 161 & 14 \\
\hline
\end{tabular}

${ }^{1} B W$ birth weight $(\mathrm{kg}), W 8$ weight $(\mathrm{kg})$ at 8 months of age, $W W$ weaning weight $(\mathrm{kg}), W 18$ weight $(\mathrm{kg})$ at 18 months, $A D G 8$ average daily gain $(\mathrm{g})$ to 8 months, $A D G W$ pre-weaning daily gain (g), $A D G 18$ post-weaning daily gain (g) up to 18 months, $A G E W$ age at weaning (days)

${ }^{2} A B$ Ankole $\times$ Brown Swiss, $A F$ Ankole $\times$ Holstein Friesian, $A J$ Ankole $\times$ Jersey, $A S$ Ankole $\times$ Sahiwal, $A J x S$ AJ $\times$ Sahiwal, $A S x J$ AS $\times$ Jersey those of AS, AJ, AJXS, and ASxJ crosses (Table 3). The mean $\mathrm{BW}$ of AF observed in this study was higher than that reported with Sanga $\times$ Friesian cattle in Ghana $(23.9 \mathrm{~kg}$ ) (Apori and Hagan 2014). For the same genotype (AF) investigated in Democratic Republic of Congo, Kibwana et al. (2015) reported birth weight of $23.8 \mathrm{~kg}$ in non-supplemented group of animals and $24.8 \mathrm{~kg}$ in supplemented group. In other crossbreeding programs lighter, comparable or heavier birth weights were reported. Segura-Correa et al. 2017 reported $33.3 \mathrm{~kg}$ birth weight in Brown Swiss $\times$ Guzerat in Mexico, while in Ethiopia Haile et al. (2011) reported $26 \mathrm{~kg}$ in Friesian $\times$ Boran.

\section{Weight at 8 months}

The comparison of mean weight for AF at 8 months was not done because literature was not available. However, in other crossing breeding programs involving Friesian Obese et al. (2013) reported $94.2 \mathrm{~kg}$ in Friesian $\times$ Sanga at the age of 7 months in Ghana, while in Ethiopia Haile et al. (2011) reported $92.1 \mathrm{~kg}$ in Friesian $\times$ Boran at 6 months of age.

\section{Weaning weight}

The weaning weight (both WWadj and WW) for AF in this study was higher than the mean $(148.7 \mathrm{~kg})$ reported by Sottie et al. (2009) in Sanga $\times$ Friesian at the age of 365 days in Ghana and in the same station Obese et al. (2013) reported $128 \mathrm{~kg}$ for the same breed and age. In Gambia, Diack et al. (2004) reported 95.5 and $95.0 \mathrm{~kg}$ at 300 days in Friesian $\times$ N'dama and Jersey $\times$ N'dama, respectively. Segura-Correa et al. 2017 reported higher WW (178.2 kg) in Brown Swiss $\times$ Guzerat at the age of 210 days in Mexico. 
Table 3 Least Square Means by breed group, sex, and season for pre- and post-weaning traits of Ankole crossbreds

\begin{tabular}{|c|c|c|c|c|c|c|c|c|c|}
\hline \multirow[t]{2}{*}{ Variable $^{1}$} & \multicolumn{9}{|l|}{ Trait $^{2}$} \\
\hline & BW & W8 & WWadj & WW & W18 & ADG8 & ADGW & ADG18 & AGEW \\
\hline \multicolumn{10}{|c|}{ Breed group } \\
\hline $\mathrm{AB}$ & $27.9^{\mathrm{a}}$ & $132.2^{\mathrm{a}}$ & $172.7^{\mathrm{a}}$ & $167.7^{\mathrm{b}}$ & $203.4^{\mathrm{c}}$ & $0.435^{\mathrm{a}}$ & $0.458^{\mathrm{a}}$ & $0.315^{\mathrm{b}}$ & $307.3^{\mathrm{c}}$ \\
\hline $\mathrm{AF}$ & $28.4^{\mathrm{a}}$ & $126.4^{\mathrm{ab}}$ & $173.5^{\mathrm{a}}$ & $182.0^{\mathrm{a}}$ & $237.7^{\mathrm{a}}$ & $0.413^{\mathrm{ab}}$ & $0.433^{\mathrm{ab}}$ & $0.395^{\mathrm{a}}$ & $353.8^{\mathrm{a}}$ \\
\hline $\mathrm{AJ}$ & $25.8^{\mathrm{b}}$ & $118.4^{\mathrm{dc}}$ & $152.8^{\mathrm{b}}$ & $153.1^{\mathrm{c}}$ & $218.4^{\mathrm{bc}}$ & $0.387^{\mathrm{bc}}$ & $0.396^{\mathrm{c}}$ & $0.341^{\mathrm{b}}$ & $325.7^{\mathrm{bc}}$ \\
\hline AS & $27.5^{\mathrm{a}}$ & $122.7^{\mathrm{bc}}$ & $156.1^{\mathrm{b}}$ & $151.8^{\mathrm{c}}$ & $219.2^{\mathrm{bc}}$ & $0.398^{\mathrm{b}}$ & $0.400^{\mathrm{bc}}$ & $0.351^{\mathrm{b}}$ & $310.0^{\mathrm{c}}$ \\
\hline AJxS & $27.7^{\mathrm{a}}$ & $115.7^{\mathrm{d}}$ & $159.3^{\mathrm{b}}$ & $165.1^{\mathrm{b}}$ & $226.9^{\mathrm{ab}}$ & $0.368^{\mathrm{c}}$ & $0.399^{\mathrm{bc}}$ & $0.357^{\mathrm{ab}}$ & $343.3^{\mathrm{ab}}$ \\
\hline ASxJ & $27.5^{\mathrm{a}}$ & $123.1^{\mathrm{bc}}$ & $159.2^{\mathrm{b}}$ & $164.5^{\mathrm{b}}$ & $223.5^{\mathrm{ab}}$ & $0.398^{\mathrm{b}}$ & $0.398^{\mathrm{c}}$ & $0.359^{\mathrm{ab}}$ & $345.7^{\mathrm{a}}$ \\
\hline \multicolumn{10}{|l|}{ Sex } \\
\hline $\mathrm{F}$ & $27.0^{\mathrm{a}}$ & $119.5^{\mathrm{a}}$ & $161.3^{\mathrm{a}}$ & $164.9^{\mathrm{a}}$ & $229.5^{\mathrm{a}}$ & $0.386^{\mathrm{b}}$ & $0.412^{\mathrm{a}}$ & $0.393^{\mathrm{a}}$ & $339.3^{\mathrm{a}}$ \\
\hline M & $27.9^{\mathrm{b}}$ & $125.9^{\mathrm{b}}$ & $165.2^{\mathrm{a}}$ & $164.6^{\mathrm{a}}$ & $216.9^{\mathrm{b}}$ & $0.410^{\mathrm{a}}$ & $0.429^{\mathrm{a}}$ & $0.333^{\mathrm{b}}$ & $323.2^{\mathrm{b}}$ \\
\hline $\mathrm{U}$ & $27.5^{\mathrm{a}}$ & $123.9^{\mathrm{b}}$ & $160.3^{\mathrm{a}}$ & $162.6^{\mathrm{a}}$ & $218.2^{\mathrm{b}}$ & $0.402^{\mathrm{ab}}$ & $0.400^{\mathrm{a}}$ & $0.332^{\mathrm{b}}$ & $330.4^{\mathrm{ab}}$ \\
\hline \multicolumn{10}{|l|}{ Season } \\
\hline SDS & $26.5^{\mathrm{a}}$ & $121.2^{\mathrm{b}}$ & $162.2^{\mathrm{ab}}$ & $166.8^{\mathrm{a}}$ & $228.2^{\mathrm{a}}$ & $0.395^{\mathrm{a}}$ & $0.411^{\mathrm{a}}$ & $0.384^{\mathrm{a}}$ & $340.8^{\mathrm{a}}$ \\
\hline LRS & $28.1^{\mathrm{b}}$ & $126.7^{\mathrm{a}}$ & $166.1^{\mathrm{a}}$ & $169.9^{\mathrm{a}}$ & $210.3^{\mathrm{b}}$ & $0.411^{\mathrm{a}}$ & $0.421^{\mathrm{a}}$ & $0.314^{\mathrm{c}}$ & $336.6^{\mathrm{ab}}$ \\
\hline LDS & $28.2^{\mathrm{b}}$ & $123.3^{\mathrm{ab}}$ & $163.1^{\mathrm{ab}}$ & $162.5^{\mathrm{ab}}$ & $220.9^{\mathrm{a}}$ & $0.398^{\mathrm{a}}$ & $0.418^{\mathrm{a}}$ & $0.342^{\mathrm{b}}$ & $325.1^{\mathrm{ab}}$ \\
\hline SRS & $27.0^{\mathrm{a}}$ & $121.3^{\mathrm{b}}$ & $157.7^{\mathrm{b}}$ & $156.9^{\mathrm{b}}$ & $226.6^{\mathrm{a}}$ & $0.394^{\mathrm{a}}$ & $0.406^{\mathrm{a}}$ & $0.372^{\mathrm{a}}$ & $321.4^{\mathrm{b}}$ \\
\hline
\end{tabular}

${ }^{1} A B$ Ankole $\times$ Brown Swiss, $A F$ Ankole $\times$ Holstein Friesian, $A J$ Ankole $\times$ Jersey, $A S$ Ankole $\times$ Sahiwal, $A J x S$ $\mathrm{AJ} \times$ Sahiwal, $A S x J$ AS $\times$ Jersey, $F$ female, $M$ male, $U$ calves with unknown sex, $S D S$ short dry season (Jan-Feb), LRS long rainy season (Mar-May), LDS long dry season (Jun-Aug), SRS short rainy season (Sep-Dec)

${ }^{2} B W$ birth weight $(\mathrm{kg}), W 8$ weight $(\mathrm{kg})$ at 8 months of age, $W W$ weaning weight $(\mathrm{kg}), W 18$ weight $(\mathrm{kg})$ at 18 months, $A D G 8$ average daily gain (g) to 8 months, $A D G W$ pre-weaning daily gain (g), $A D G 18$ postweaning daily gain (g) up to 18 months, $A G E W$ age at weaning (days). Mean values with different letters are significantly different $(P<0.05)$

\section{Weight at 18 months}

For body weight at 18 months in this study, AF outperformed other crossbreds. Weights of AF (238 kg) were comparable to those $(248 \mathrm{~kg}$ ) obtained on farm in Ugandan AF cross of similar age (Galukande 2010). Lower weights $(159.9 \mathrm{~kg})$ were reported by Obese et al. (2013) in Sanga-Friesian crossbreds. In Gambia, Diack et al. (2004) reported comparable results 246.1 and $235.8 \mathrm{~kg}$ in Friesian $\times$ N'dama and Jersey $\times$ N'dama, respectively; however, unlike the present study, these were body weights at 3 years of age.

\section{Average daily weight gain}

The daily average weight gains for AF obtained in this study were higher than those reported in Ghana, where Sottie et al. (2009) obtained 0.32 and $0.27 \mathrm{~kg}$ for ADG8 and ADG18, respectively, in Sanga $\times$ Friesian and in the same station Obese et al. (2013) reported 0.33 and $0.23 \mathrm{~kg}$ for ADG7 and ADG12, respectively. In Ethiopia, Haile et al. (2011) reported $0.511 \mathrm{~kg}$ for ADG6 and $0.302 \mathrm{~kg} \mathrm{ADG} 24$ in Freisian $\times$ Boran.

\section{General comments}

In general, $\mathrm{AB}$ seems to do very well during the first 8 or 10 months, as well as or better than the AF cross. However, after weaning, growth decreased and the W18 was the lowest among all breed groups. By that time, the AF was the heaviest. Because the weaning age for AF was higher than for $\mathrm{AB}$, the actual weight at weaning for AF was higher than all other breed groups. Because the time for weaning is decided subjectively, based on the perceived survivability, it is difficult to know if this higher weaning age for AF is truly warranted. If AF calves really need to be older (and thus heavier) when weaned, it would be interesting to find out why this would be true. This would require a more dedicated study with predetermined weaning ages and possibly also studies of grazing behavior.

Even though the AF cross was the heaviest at 18 months, the superiority compared with, say, AJ was only about $20 \mathrm{~kg}$. The difference in body weight for purebred Holstein Friesian and Jersey at that age would be expected to be in the range of 130-139 kg under good conditions (e.g., Heinrichs and Hargrove 1987), which would lead to an expected difference between AF and AJ of 65-70 kg, disregarding any heterosis. The rather small differences between breed groups are 
Fig. 1 The trend of birth weight (BW), weight at 8 months (W8), age-adjusted weaning weight (WWadj), and weight at 18 months (W18) over birth years

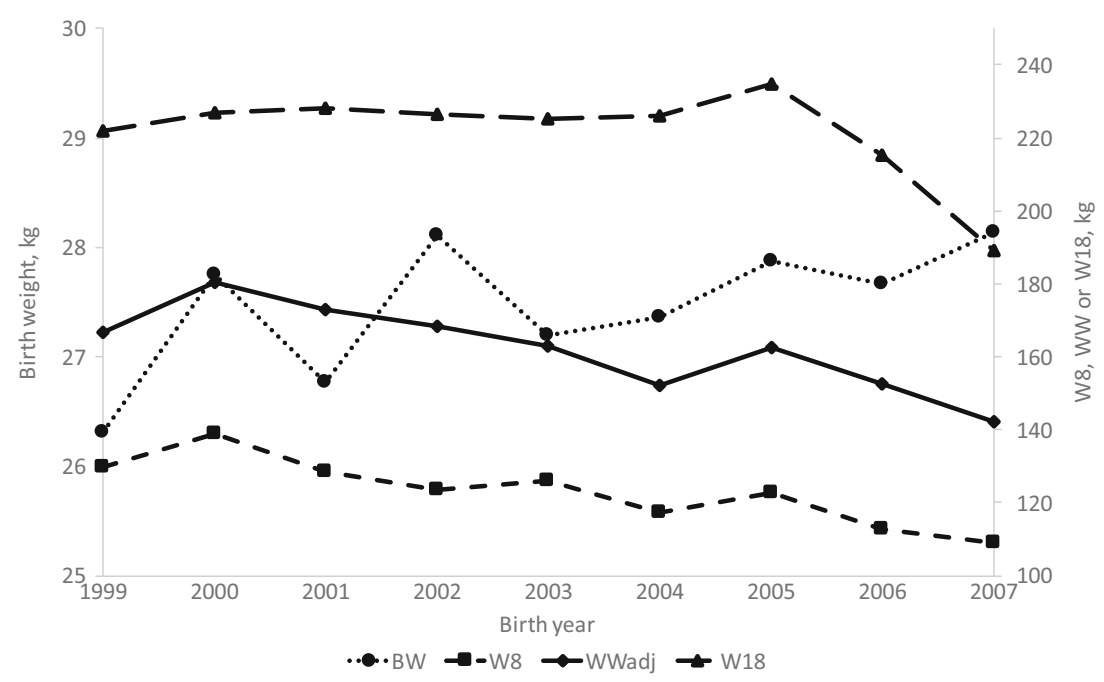

probably because environmental conditions (e.g., feed, but also temperature and humidity stress) do not allow for the full expression of the genetic potential in the exotic crosses.

It would also be of great interest to follow up these breed groups after slaughter. Perhaps the difference in carcass weight would not show the same pattern as those for, say, W18. It could be hypothesized that the largest difference in $\mathrm{W} 18$ (between $\mathrm{AF}$ and $\mathrm{AB}$ ) would be diminished or evened out, if $\mathrm{AB}$ has a better dressing percentage than $\mathrm{AF}$. According to Bozkurt and Dogan (2016), the dressing percentage at 18 months of age was $53.6 \%$ for $\mathrm{AB}$ and $52.6 \%$ for $\mathrm{AF}$.

\section{Sex}

In many cattle studies, males are heavier than females at all ages (e.g., Casas et al. 2011). Also in our study, males remained significantly heavier than females up to 8 months of age; however, the relation between sexes was reversed at weaning to 18 months of age. This could be due to sale of fastgrowing male calves at 6 months and older depending on the demand, while most of the female calves were kept for replacement. In studies with less severe culling of males, males tended to be heavier than females up to 18 months or 2 years; however, in one study, females $(164.3 \mathrm{~kg})$ were heavier than males (151.4 kg) at 18 months of age (Obese et al. 2013).

\section{Season}

Some of the body weight and weight gain traits were affected by season of birth. Heavier calves were born in LRS and LSD, and those born in LRS tended to be heavier up to weaning. However, at 18 months, they had the lowest weight. Of course, season of birth should be viewed upon as a series of seasons following each other and this makes interpretation very difficult for such a long period as 18 months. Even for
Fig. 2 The trend of average daily gain to 8 months (ADG8), to weaning (ADGW), and to 18 months (ADG18) over birth years

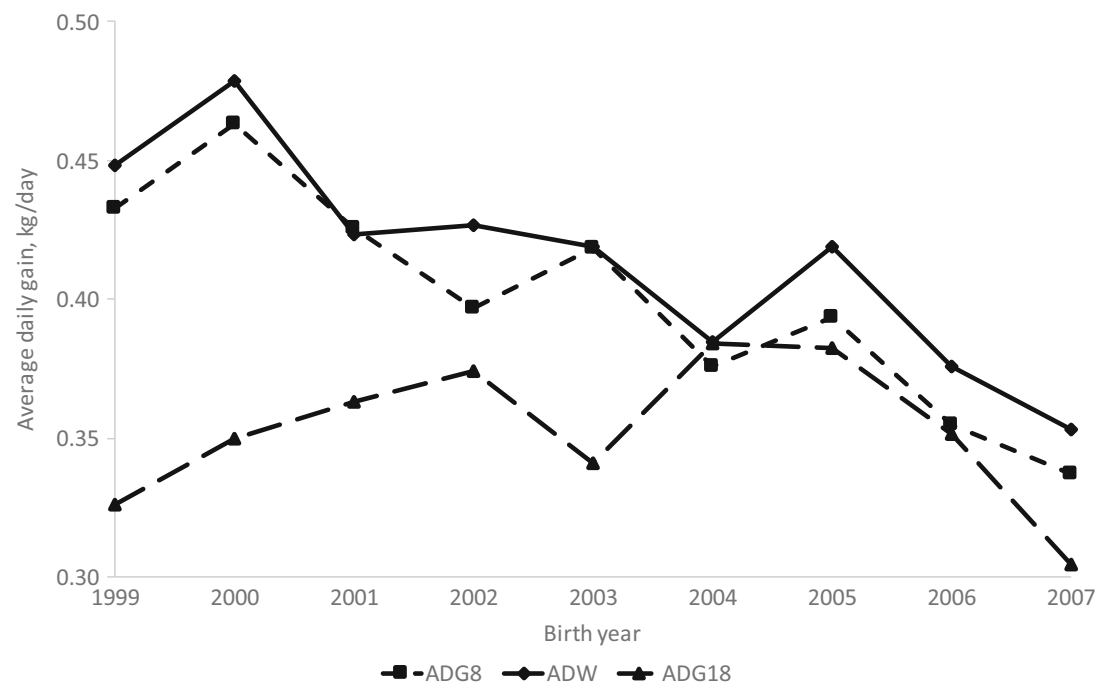


$\mathrm{BW}$, it is rather the season during pregnancy than the actual season at birth that is influencing the weight. It may be that some of these animals enter into an (un)favorable combination of growth or development period and season.

\section{Time trends}

There was a significant increase in BW over the years, but also a significant decrease in both W8 and WWadj as well as for corresponding growth rates (ADG8 and ADGW) (Figs. 1 and 2). Percentage-wise, this is more than $2 \%$ decrease of the live weight per year for W8 and WWadj and $3 \%$ for the growth rates. The reasons for this decline are unknown but could be related to herd variability in management practices and climatic conditions, whether this trend is particular to the Songa station is also unknown but should be a reason for careful monitoring of the future environmental conditions.

\section{Conclusion}

The main conclusion from this study is the existence of differences in the performance of different Ankole crossbreds. Generally, AF was heavier compared to other breed groups; however, the difference in body weight was small compared to its expected genetic potential. This highlights the importance of environmental factors in contributing to the variation in preand post-weaning growth traits.

Acknowledgements The authors thank the University of RwandaSweden program for financial support and the Rwanda Agricultural Board (RAB) staff for all their work during data gathering process, which was strenuous.

\section{Compliance with ethical standards}

Conflict of interest The authors declare that they have no conflict of interest.

Open Access This article is distributed under the terms of the Creative Commons Attribution 4.0 International License (http:// creativecommons.org/licenses/by/4.0/), which permits unrestricted use, distribution, and reproduction in any medium, provided you give appropriate credit to the original author(s) and the source, provide a link to the Creative Commons license, and indicate if changes were made.

\section{References}

Apori, S.O. and Hagan, J.K., 2014. The effect of non-genetic factors on the reproductive performance of Sanga and Friesian x Sanga crossbred dairy cattle breeds kept under hot and humid environment. Tropical Animal Health and Production, 46, 1045-1050.
Bozkurt Y. and Dogan C. 2016. Physical performance and carcass characteristics of Holstein and Brown Swiss cattle grown in an intensive beef system. Scientific Papers. Series D. Animal Science, Vol. LIX, ISSN 2285-5750, 75-78.

Casas, E., Thallman, R. M. and Cundiff, L. V. 2011. Birth and weaning traits in crossbred cattle from Hereford, Angus, Brahman, Boran, Tuli, and Belgian Blue sires. J. Anim. Sci. 89:979-987.

Diack, A., Sanyang, F. B. and Corr, N. 2004. Survival, growth and reproductive performance in $\mathrm{F} 1$ crossbred cattle produced and managed on station in the Gambia. Livestock Research for Rural Development. Vol. 16, Art. \#70. Retrieved May 13, 2017, from http://www.lrrd.org/lrrd16/9/diac16070.htm.

Galukande, E. 2010. Comparison of production systems with purebred Ankole vs. crossbred Ankole-Friesian Animals on-farm using a combined cross-sectional and longitudinal approach (Kiruhura district of Uganda). University of Natural Resources and Applied Life Sciences, Vienna.

Haile, A., Joshi., B.K., Ayalew, W., Tegegne, A., Singh, A., 2011. Genetic evaluation of Ethiopian Boran cattle and their crosses with Holstein Friesian for growth performance in central Ethiopia. J Anim Breed Genet. 2011;128(2):133-40.

Heinrichs, A.J and Hargrove G.L. 1987 Standards of weight and height for Holstein Heifers: Journal of Dairy Science, Volume 70 , Issue 3 , 653-660.

Kibwana, D.K; Makunyavira, A.M.; Hornomic, J.L. 2015. Effect of improved feeding and housing, Friesian blood level and parity on milk production of Ankole x Friesian cows. Pakistan Veterinary Journal (2015), 35(1), 76-80.

Kugonza, D.R., Nabasirye, M., Mpairwe, D., Hanotte, O. and Okeyo, A.M. 2011. Productivity and morphology of Ankole cattle in three livestock production systems in Uganda. Anim. Genet. Res., 48: 1322.

Mutimura, M., Ebong, C., Rao, I.M., Ignatius, V.N. (2016). Change in growth performance of crossbred (Ankole $\times$ Jersey) dairy heifers fed on forage grass diets supplemented with commercial concentrates. Trop Anim Health Prod (2016) 48: 741.

Obese, F.Y., Acheampong, D. A. and Darfour-Oduro, K.A. 2013. Growth and reproductive traits of Friesian $\times$ Sanga crossbred cattle in the Accra plains of Ghana. African J. Food, Agric., Nutri. Dev., 13: 7357-7371.

Pravia, M.I., Ravagnolo, O., Urioste, J.I., Garrick, D.J. 2014. Identification of breeding objectives using a bioeconomic model for a beef cattle production system in Uruguay. Livestock Science, v.160, p.21-28. https://doi.org/10.1016/j.livsci.2013.12.006.

SAS, 2012. Statistical Analysis System. Version 9.4 for windows. SAS Institute Inc., Cary NC, USA

Segura-Correa, José C.; Magaña-Monforte, Juan G.; Aké-López, Jesús R.; Victor M.; Hinojosa-Cuellar, José A.; Osorio-Arce, Mario M. 2017 Breed and Environmental effects on birth weight, weaning weight and Calving Interval of zebu cattle in South Eastern Mexico. Tropical and Subtropical Agroecosystems, vol. 20, núm. 2, pp. 297-305

Sottie, E.T., Darfour-Odur, K.A., and Okantah, S.A. 2009. Comparative studies on growth traits of Sanga and Friesian-Sanga crossbred calves raised on natural 85 pasture on the Accra Plains of Ghana. Tropical Animal Health and Production 41:321-328.

Roschinsky, R., Kluszczynska, M., Sölkner, J., Puskur, R., \& Wurzinger, M. (2015). Smallholder experiences with dairy cattle crossbreeding in the tropics: From introduction to impact. Animal, 9(1), 150-157. doi:https://doi.org/10.1017/S1751731114002079

Wurzinger, M., Mirkena, T., Sölkner, J., 2014. Animal breeding strategies in Africa: current issues and the way forward. J. Anim. Breed. Genet. 131, 327-328. 